\title{
IMPACT OF THE BUSINESS MINDSET ON STUDENT PERCEPTIONS OF THE NON-COMPETE AGREEMENT
}

Lester C. Reams, JD, DPA MPH, Associate Professor Department of Business, Mount Saint Mary's University, Los Angeles, California USA (USA)

https://orcid.org/0000-0002-6883-7072

e-mail:1ester.reams6@gmail.com

Received: November 04, 2020

Approved for printing: December 28, 2020

Published: February 26, 2021

Raems L. C. (2020). Impact of the business mindset on student perceptions of the non-compete agreement. Bulletin of Taras Shevchenko National University of Kyiv. Public Administration, (13), 61-69. https://doi.org/10.17721/2616-9193.2021/13-7/9

\begin{abstract}
One of the major tasks of the Business Law course is the acquisition and right application of legal concepts by business and public administration students. This article makes an insight into the inconsistency exposed through surveying the students' opinions on non-compete agreements. The study bases on the hypothesis that the business mindset which dominates American society influences the students' perception of this legal concept. Pursuing the aim to unveil the cognitive factors influencing the students' perception, the author traces the formation and historical dynamics of the concept of business mindset in the US, and its influence on popular attitudes to legal concepts resulting in the positive perception of non-compete agreement. Contributing to such positive perception was creation of a delusional myth compensating for the harsh reality of capitalism and euphemizing the words 'capitalism' and 'capitalist'. The author offers actions to address students' perception, in order to bring their subjective views and attitudes in compliance with legal reality and scientific worldview.

Keywords: business mindset, popular attitude, perception, non-compete agreement, business law, education for business and public administration, euphemizing
\end{abstract}

\section{Introduction}

In my business law courses, I have asked a simple discussion question regarding the non-complete agreement in employment contracts with the idea that such a restriction would not be favored by my students, since capitalism promotes the use of competition. Hence, if an employee works for a company, gains skills, and wants to make more money. He or she should have the freedom to leave that job if the employees' current employer cannot pay more to keep the employee. To my shock the students argued that the business must protect itself by using these agreements and the employee should be restricted. Yet, personally, there was a split where some would not be upset if their job restricted them. While others indicated that they would be upset if their job restricted them. Where did this come from and what has happened to the notion of competition? Therefore, the aim of this article is to determine what has influenced the public's perception that has change the students' perspective on the non-compete agreement.

In order to determine what has occurred in the student perception, this article will discuss the following research objectives (1) identify and review the history of the business mindset; (2) determine how this Business Mindset Influenced Perceptions of Business 90s and 2000s, competition and created a myth; (3) describe and review the history of the non-compete agreement along with the factors that caused the non-compete clause to evolve; (4) identify the actions taken to address the non-compete agreement and (5) actions that may be taken to address students' perception. 


\section{Methods}

Interdisciplinary in its nature, this study employs a complex methodology combining cognitive research methods such as observation, survey, historical and synchronous analysis of concepts, with legal analysis and commentary, case studies and interpretation, along with multidisciplinary review of literature.

In surveys and observational studies, the research cohort was composed of approximately $100 \mathrm{MBA}$ students, including full-time and part-time students (working adults) who were preparing to graduate as managers. Their attitudes and perceptions were studied through observation of their behaviors and reactions during class discussions, through interviews and focused surveys. The obtained results that were analyzed and interpreted were based on legal concepts and theories that allowed the author to formulate conclusions and recommendations to address the students' perceptions of the non-compete agreement.

\section{The study}

The core concept of this study - that of MINDSET is defined as a set of assumptions, methods, or notions held by one or more people or groups of people ("Mindset," 2020); a person's way of thinking and their opinions (Cambridge Dictionary, n.d.). A mindset can also be seen as arising out of a person's world view or philosophy of life (Funk, 2001); it is defined in dictionaries as "a fixed mental attitude or disposition that predetermines a person's responses to and interpretations of situations" (The Free Dictionary), "the ideas and attitudes with which a person approaches a situation, especially when these are seen as being difficult to alter. (World English Dictionary: quoted from: Sources of Insight).

Variously conceptualized across disciplines (French, 2016), the concept of mindset is associated with individual and collective perceptions, beliefs, attitudes, worldview, motivation, decision-making, and action (Gollwitzer, 2012). The types of mindsets explored by cognitive psychologists are classified based on different criteria, depending on the author's research focus: growth mindset vs fixed mindset (Dwek, 2007), deliberative mindset vs the implemental mindset (Gollwitzer, 2012; Doerflinger \& Gollwitzer, 2020) etc.

The focus of this research is on the formation and core features of the BUSINESS MINDSET as an important distinctive value of the American society which for centuries has driven its development as well as perception and interpretation of events and the respective actions.

Peter M. Gollwitzer views mindsets as "various modes of information processing at different phases of goal pursuit" (NYU, 2020, para. 4). Studying the perceptions of the MBA students and their attitudes to various legal concepts important for their future employment and business activities, we expected that, aspiring towards the goal of gainful employment and successful competitive career, the students should have a positive attitude to laws protecting employees' rights and granting them more freedom of career choices in the future.

Surprisingly, while discussing the meaning of non-compete agreement in the employment contracts, it was discovered that students were almost unanimously on the side of the employer and not the employee. Approximately, $87 \%$ of all answers stated the positive or tolerant perception of non-compete agreement.

Below are some examples of the students' answers:

Student 1: "The business must protect itself by using these agreements and the employee should be restricted".

Student 2: "The agreement is fine and they should be available to any employee that deals with sensitive information".

Student 3 "I don't think I would be upset if I had to sign a non-compete agreement for a year".

Student 4: "I would not be upset if a prospective employer asked me to agree to a one-year covenant not to compete as long as I understand the reason behind it. Understanding the non-compete agreement will help me to run a business of my own one day".

Student 5: "It doesn't seem fair to train your star workers to greatness then have them run off to your competitor because they are offered a higher salary".

This perception prevailed despite the fact that the students were explained in their Business Law course that in certain jurisdictions non-compete agreements have been deemed unenforceable as a result of their negative impact on the economy (Martinez, 2020). 
We hypothesized that the students' positive perception of non-compete agreements, which contradicts both their interests and legal reality, roots in the deeper structures of their mind governing their attitudes and channeling their perception in a particular way. This prompted making a specialized insight into the formation and development of the business mindset which determines the perception of business-related notions, behaviors, decisions etc. The results of this study and their discussion are presented below.

\section{Results and Discussion}

\section{History of the Business Mindset}

A business is an organization which seeks to make a profit through individuals working toward common goals (Pride, Hughes, and Kapoor, 2015). The Business mindset is a way of thinking that enables a person to uncover and see problems as opportunities, and then turn those opportunities into a business. It is an understanding that everything around us is the result of someone having an idea and then executing it (Nastor, n.d.). It is unclear who or when the use of the term "Business Mindset" began. However, it began to be heavily marketed in conjunction with workshops that trained people on becoming successful entrepreneurs. Catch phrases such as business spirit, business mentality also appeared as well. The use of this term may have been encouraged with the success of Carol Dweck's 2007 book "Mindset: The New Psychology of Success (Dweck, 2007).

Unfortunately, the definition of Business Mindset may provide a clue on the reason the non-compete clause/agreement was incorporated in standard employee contracts. Understanding this mindset may show the actions needed towards creating and maintaining a business. To determine this, the author will review the historical business behavior, business ethics theories, level of power and the perception of business in the United States.

In his book "The Age of Betrayal" (2007) Jack Brady indicated that it was not until after the civil war, during the Unites States' industrial revolution, that the influence of business would take place. This revolution was known as the Gilded Age which began in 1870 and ended in 1900. The term Gilded Age was used by historians in the 1920s, who took the term from one of Mark Twain's lesser known novels, The Gilded Age: A Tale of Today, 1873 (Brady, 2007). It was during this time that the United States' business mindset was firmly established through the Gilded Age robber barons James J. Hill, Henry Ford, Andrew Carnegie, Cornelius Vanderbilt, and John D. Rockefeller and others. Brady pointed out that although the industrialization of the United States brought wealth to a handful of people, this industrial revolution left the remaining citizens to struggle as wage laborers. John Naughton (2012) summed up the behavior and mindset of business when he stated: "In addition to building a modern industrial state, these gents amassed huge fortunes for themselves using a raft of dubious techniques, including fraud, stock-dilution, the bribing of corrupt politicians, the creation of secret cartels (ironically called "trusts") and the ruthless exploitation of poorly paid, non-unionized workers - which is why Matthew Josephson dubbed them "robber barons" in his book of the same title" (Naughton 2012, p. 5-6).

Since the Gilded Age, the wealthy have managed to stay in power to protect their own self-interest either through money, lobbyism or becoming politicians. While this has been beneficial for the wealthy, small and medium size businesses have not had the opportunity to participate unless they have become members of organizations that represent their interest, such as local Chamber of Commerce or business associations. Unfortunately, large corporations are also members of these organizations as well, which tends to drown out the smaller businesses' voices. One aspect that is encouraged by large corporations and business consultants is that small and medium size business owners incorporate tools and approaches that have been used by corporations so that small or medium size businesses can protect their self-interest and maximize their profits as well.

During the $21^{\text {st }}$ Century there has been an attempt to redefine the business mindset as a way of thinking that enables a person to uncover and see problems as opportunities, and then turn those opportunities into a business. It is an understanding that everything around us is the result of someone having an idea and then executing it (Nastor, n.d.). In the light of this redefinition, Naughton (2012) concluded that new tech moguls 
such as Mark Zuckerberg, Jeff Bezos and others may look cool and have soothing bedside manners, but in the end these guys are in business not just to make money, but to establish sprawling, quasi-monopolistic commercial empires. And they will do whatever it takes to achieve those ambitions" (Naughton 2012, p. 5). Therefore, the business behavior of using a non-compete clause or agreement would be one tool that would be a benefit to business based on the business mindset.

\section{How this Business Mindset Influenced Perceptions of Business 90s and 2000s, Competition and Created a Myth}

Now that the behavior of the concept of Business Mindset has been established through historical observation, it is important to determine the influence such a mindset had on the perception of business in the 90's and 2000's. Assessing this influence will assist in answering the question, where did the notion come from that business must protect itself by using these agreements to restrict employees? Even more important, what has happened to the notion of competition?

Business in the 90's

Prior to the 90's and 2000's businesses were organized as Command and Control organizations based on the scientific management approach developed in 1910 by Frederick Taylor and Alfred Sloan. In his book "The Principles of Scientific Management", Taylor asserted that productivity would increase by optimizing and simplifying of jobs. He added that workers and employers must work together (Taylor, 2014). Dichter (1992) provided an assessment of command and control and indictated the following.

"The Command and Control (C\&C) organization, at its peak, was a highly refined system predicated on stability and forged by a particular set of technological, market, and demographic forces. Single purpose machinery, stable mass markets, and a semi-skilled workforce were all mutually supporting. Together they shaped a predominant strategy of standardized, high-volume production and a $\mathrm{C} \& \mathrm{C}$ organization. The essence of a $\mathrm{C} \& \mathrm{C}$ organization is the separation of decision making and implementation: managers and staff make decisions; middle managers transmit and coordinate; workers implement." (Dichter, 1992, p 2)

Based on this description, the business mindset of "Command and Control" was a departure from the mindset of the "Robber Baron" where there was an emphasis on collaboration at all levels instead of exploitation. Unfortunately, the true implementation was a top-down management where all decision making was made at the top and that each employee was compartmentalized into specific role with little collaboration. This approach lasted from 1910 to 1989 and provided a methodical growth for each generation of business leaders.

Unfortunately, by the 1990, Dichter stated that markets had fragmented requiring faster response time to maintain customers. He added that technological changes had improved where the capturing manipulating and transmitting information electronically allowed decision to be made faster without losing focus or control (Dichter, 1992). The overall shift in the 90 was to provide value to the customer. The 90 also revealed a change in labor where the workers were better educated and demand greater participation and variety in their jobs. There was a feeling of optimism because of opportunity to change from the Command and Control mindset to something new. This period also maintained the business dynamism of a healthy economy where businesses are created and destroyed but in the process there is an environment of competition. This environment results in the consumers benefitting from new ideas and low prices. Unfortunately, as the 1990 progressed, the business dynamism began to slow down. Wessel (2018) asserted that the slow down began in the retail sector with the appearance of Walmart. He observed that although the number of retailers starting up and dying off plunged, the industry became more productive. He dubbed this "the Walmart effect," (Wessel, 2018).

\section{Business in the 2000's}

By the 2000's the Walmart effect had permeated to other business industries such as airlines, beer, 
pharmaceuticals and hospitals. These industries wielded market power in ways that prevented rivals from emerging and thriving. The winners were winning bigger, while the number of new start-ups was falling. Much of this is not because of the creation of unique products or innovation, but because of the return to the anticompetitive behavior and mindset that began in the Gilded Age. In its new iteration, the focus of this behavior/mindset allows a firm or group of firms to restrict inter-firm competition to maintain or increase their market and profits without providing goods and services at a lower cost or of higher quality. But, as mentioned earlier, this behavior/mindset is not just to make money, but to establish sprawling, quasi-monopolistic commercial empires.

\section{The Message/Myth-Job Creators}

In 2011, Moody (2011) stated that a Republican political consultant named Frank Luntz began advising republican politicians remove the word capitalism and related words surrounding wealth as result of the Occupy Wall Street movement. This movement caused Americans to negatively view capitalism. The word "Capitalism" would be replaced with either "economic freedom" or "free market", and "job creator" would replace Entrepreneur. These and other replacement words were shared with Republican elected officials in various states and the media which would then share the words with the public (Moody, 2011). Because of the actions by Luntz the myth surrounding the wealthy being job creators was started. Johnson (2013) has stated: "Capitalism is a system organized around the single-minded pursuit of wealth. Business is simply a way of turning wealth into more wealth...the simple truth that creating jobs is not now and never has been what capitalism is about. Capitalism has never been about the well-being of anyone but the capitalist and their relations unless caring about people or families or communities can in some way enhance the bottom line" (Johnson, 2013). Hence, the more money they received the more jobs they would create. Although it was a myth, this thinking tended to be adopted by new business owners as a way of supporting their community.

Blodget, (2013) added that to suggested that the "Rich" alone are responsible for the jobs that sustain the other 300 million Americans is the height of self-importance and delusion. Both Blodget and Johnson conclude that the real job creation is due to a healthy economy that pays and supports middle-class consumers. Blodget stated that a healthy economic ecosystem surrounding the company starts with the company's customers where the company's customers buy the company's products. This, in turn, channels money to the company and allows the company to hire employees to produce, sell, and service those products. If the company's customers and potential customers go broke, the demand for the company's products will collapse. When this occurs, the company's jobs will disappear, regardless of what the entrepreneurs or investors do to avoid the problem (Blodget, 2013). Johnson (2013) concluded by summarizing that the image of the wealthy as job creators is a myth, a myth that goes unchallenged in no small part because their wealth gives them tremendous power. He observed that they seem so fond of reminding us (the public), they can always decide to withhold their wealth or go somewhere else and leave us high and dry with no jobs at all. Johnson (ibid) adds that the public is supposed to keep quiet and not challenge that power, or at least not too strongly or for too long, lest they become annoyed. Johnson concluded with a question when he indicated: "This is the reality behind the myth, and so we must answer, which will it be?" (Johnson, 2013 para 19)

Thus, through conceptual analysis of BUSINESS MINDSET and historical observation of the formation and evolution of this concept we may conclude that, partially due to its transformative influence on the economy, partially through deliberate creation of a myth, businesses and business owners have come to be conceptualized as benefactors of the society: creators of social wealth, jobs, etc., on whom the rest of the society depend for their well-being. The creation of this 'mythologized' concept has been greatly supported by the wealthy accumulating political power, as well as consultants and media controlled by them. Mere euphemization of language expressions capitalism as "economic freedom" or "free market", capitalist as "job creator" resulted in enhancing positive attitudes and perception of business and negative attitudes to anybody/anything that counters or threatens them, and, therefore, the well-being of the whole society. Such an attitude, in our opinion, determined the perception of non-compete agreement/clause as a tool for the businesses to protect themselves.

As has been shown above, the delusional myth compensates for the harsh reality of capitalism allowing business owners to use it to justify any tool to maintain wealth, power and control. Hence, it can be concluded 
that the use of non-compete agreement/clause is a symptom of the business mindset which is an element of the capitalist culture. When connecting the points just mentioned to my students' reaction that "business must protect itself by using these agreements and the employee should be restricted," the origins of their responses appears to be perpetuated by the replacement of capitalism with friendlier terms to protect business behavior.

History of the Non-compete Agreement

The non-compete agreement was not established until the landmark decision of Mitchel v. Reynolds handed down in 1711 which created the framework for the enforcement of restraint of trade. Prior to this decision, the common law did not enforce non-compete agreements because of the restrictions such laws would have on trade. The Michel v Reynolds case provided the framework on how such restriction could be applied in different areas of business.

In modern times, Bennett (2018) indicated that the traditional use of the non-compete agreements were included in "contracts for white-collar executives or other high-profile employees who might have access to company trade secrets or develop personal relationships to clients" (Bennett, 2018 para 6). Kelton (2019) adds that normally a non-compete agreement includes specific clauses stating that the employee will not work for a competitor after his or her employment has ended. (Kelton, 2019). There was the fear of the business owners that the owner's secrets would be used by the business owner's competitor should the executive or high-profile employee leave and get hired at another company. Often with executives or high-profile employees the business would include a "golden parachute" written into the employment contract. Berman (n.d.) has stated that the "golden parachute" was not simply a lump sum of money representing gratitude for how long you've worked, but ensure that the executive or high-profile stay out of work environment for a designated length of time such as one to two years. (Berman, n.d. p 1). This would change in later years.

Non-Compete Agreement Evolution

Bennett (2018) stated that the evolution of the non-compete agreement occurred after the great recession (Bennett 2018). It was during this period where jobs were hard to come by and workers had less leverage to negotiate the terms of their employment. As a result, non-compete clauses started appearing in contracts for workers in low-wage or middle-income jobs (ibid.). The explanation for their inclusion into such contracts was that the non-compete agreement/clause was needed to protect business secrets. In books and literature as well as other media the notion of the non-compete clause was shared so that when new entrepreneurs began business, they understood that non-compete agreement/clause was a common tool of the business culture, or just part of "doing business". This made the practice honorable and acceptable when discussed with the general public. Bennett (2018), citing Jonathan Poland identified the real reasons when he stated the following: "This is about money and greed. Companies use non-compete agreements/clauses to lock up talent, restrict employee mobility and suppress wages and corporate law firms to generate hundreds of millions of dollars in revenue every year from prosecuting bogus non-compete agreement/clause cases." (Bennett, 2018, para 5) In addition, Sorenson and Marx (2016) indicated that workers subjected to noncompete agreements/clauses have experienced less career flexibility, earn less, and may need to move to a different industry or state to find employment, resulting in additional stressors for the employee. They added that non-compete agreements/clauses place restrictions on entrepreneurship which is essential for innovation and economic growth. (Sorenson and Marx, 2016) Hence, supporting the business mindset that is based on the harsh reality of capitalism enabled the non-compete agreements/clauses to evolve into a tool to maintain wealth, power, and control.

Action Taken to Address the Non-compete Agreement.

There have been state and federal actions taken to address the non-compete agreement. These actions vary from state to state. Martinez (2020) indicated that the enforcement of non-compete agreements is governed by state common law. He added that each state has enacted statutes that govern the use and limitations of such agreements. Martinez concluded that in certain jurisdictions, non-compete agreements have been deemed unenforceable as a result of the impact it has on the economy. For example, non-Compete agreements are unenforceable in California. Yet, in other jurisdictions the use of non-compete agreements is restricted to the sale of business. This occurs in North Dakota and Oklahoma. Finally, there are a number of states, such as Illinois, Maine, Maryland, New Hampshire, Rhode Island, and Washington where employers are prohibited from using 
non-compete agreement with low-wage workers.

The federal actions that have been taken have occurred through the U.S. Department of Justice Antitrust Division ("DOJ") and the Federal Trade Commission ("FTC"). Martinez (2020) points out that both organizations have focused significant attention on competition in the labor markets. Martinez added that three years ago, the DOJ announced a significant change in enforcement policy, warning corporations and executives that, going forward, it would scrutinize and even criminally prosecute "naked" no-poach and wage-fixing agreements between competing employers. Finally, Martinez indicated that the FTC held a workshop to explore an FTC rule that would significantly limit or perhaps even eliminate the use of workplace non-compete agreement/clauses in employment agreements or standalone restrictive covenant agreements. All these decisions of governmental agencies demonstrate that federal and state laws aim to support competition in the labor markets, while non-compete agreements are deemed restricting for an individual employee, and ultimately harmful for the economy.

\section{Conclusions}

The concept of BUSINESS MINDSET has historically appeared in the course of industrial revolution as the faculty of mind to uncover and see problems as opportunities, and then turn those opportunities into a business, which gave it an undoubtedly positive flavor. In the course of its historic development in 90's and 2000 's, the positive attitude to this concept was supported through deliberate creation of a myth that business and business owners are benefactors giving social wealth, jobs, etc., to the rest of the society. This was achieved, inter alia, through euphemization of language expressions: capitalism as "economic freedom" or "free market", capitalist as "job creator" etc. As a result, negative attitudes appeared to anybody/anything that counters or threatens business, and, therefore, the well-being of the whole society.

The non-compete agreements in employment contracts appeared with the aim to protect the company's trade secrets from being stolen by competitors through high-rank executives or employees and began to be viewed as a normal business practice. But after the great recession when the unemployment was very high, they started to be included into the contracts for low-wage or middle-income workers because the latters' negotiation power was limited. On the other hand, state and federal laws emerged that restricted the use of non-compete agreements because these agreements/clauses restrained competition in the labor market. This is done to promote the growth and health of the economy.

However, the MBA students in our study showed a positive perception of non-compete agreement/clause. Such perception, in our opinion, is determined by the dominance of the business mindset where businesses are perceived as supporters and benefactors of the society and therefore should be protected.

This exposes a broader problem of the dominance of popular worldview (common truths and beliefs) over the scientific worldview (laws established and proved by research, government regulations based on scholarly opinions etc.). One of the major tasks of education, including business education, is cultivating the students' scientific worldview, to make them real professionals guided in their professional decisions and activities by scientific knowledge of laws, as well as law-abiding citizens. Therefore, we implemented a series of actions to address students' perception of non-compete agreement/clause in employment contracts.

Actions that may be taken to address students' perception

Based on the results of our study, the best approach to address the students' perception is to provide more assignments that show the problems and economic effects of the use of non-compete agreements/clauses. Such assignment would include:

1. Discussion Questions that ask the student to research issue and court action that addressed noncompete agreements.

2. Papers that require the student to review cases that provide the pros and cons of using non-compete agreement.

3. Simulations that show the impact of non-compete agreements on the business and community.

4. Classroom role plays or debates so that the class can gain insight on the impact of non-compete agreements.

By taking these steps, students will gain a well-rounded understanding of non-compete agreements. 


\section{References}

Brady, J (2007) Age of Betrayal: The Triumph of Money in America, 1865-1900, PenguinRandom House New York City, 1-707.

Bennett, J (2018) Noncompete Clauses: They're not Just for Executives Anymore, The Guardian, Retrieved October 26, 2020 https://publicintegrity.org/inequality-poverty-opportunity/noncompete-clausestheyre-not-just-for-executives-anymore/

Berman, H. (n.d.) Things to Know About 'Golden Parachutes' FairyGodBoss Retrieved from https://fairygodboss.com/career-topics/golden-parachute

Blodget, H (2013) Sorry, Folks, Rich People Actually Don't 'Create The Jobs' Business Insider Retrieved from https://www.businessinsider.com/rich-people-create-jobs-2013-11

Cambridge Dictionary (n.d.) Mindset. In: Dictionary.cambridge.org. Retrieved December 17, 2020, from https://dictionary.cambridge.org/us/dictionary/english/mindset

Dichter, S. F. (1992). The Organization of the '90s. Mckinsey p. 2. Retrieved from https://www.mckinsey.com/business-functions/organization/our-insights/the-organization-of-the$90 \mathrm{~s}$

Doerflinger, J. T., \& Gollwitzer, P. M. (2020). Emotion emphasis effects in moral judgment are moderated by mindsets. Motivation \& Emotion. Retrieved from https://doi.org/10.1007/s11031-020-09847-1

Dweck, C (2007) Mindset: The New Psychology of Success. Random House publishing, NewYork City.

Kelton, W (2019) Non-Compete Agreement. Investopia. Retrieved from https://www.investopedia.com/terms/n/noncompete-agreement.asp

French II, Robert (2016). The fuzziness of mindsets: Divergent conceptualizations and characterizations of mindset theory and praxis. International Journal of Organizational Analysis. 24. 673-691. 10.1108/IJOA09-2014-0797.

Funk, Ken 2001). What is a Worldview? http://web.engr.oregonstate.edu/ funkk/Personal/worldview.html

Gollwitzer, Peter (2012). Mindset theory of action phases. 10.4135/9781446249215.n26.

Johnson, A. G. (2013) The 'Job Creator' Myth. Retrieved from https://www.agjohnson.us/essays/jobs/

Martinez, M. E., Lee, S. Donahue, L. N. Rigney, E. L, \& Smith, B. J. (2020) Competition in U.S. Labor Markets: Non-Compete Clauses Increasingly Under Fire. National Law Review Retrieved from: https://www.natlawreview.com/article/competition-us-labor-markets-non-compete-clausesincreasingly-under-fire

Mindset. (2020, December 4). In: Wikipedia. https://en.wikipedia.org/wiki/Mindset\#cite_note-1

Moody, C (2011) How Republicans are being taught to talk about Occupy Wall Street, The Ticket Retrieved October 25, 2020 https://news.yahoo.com/blogs/ticket/republicans-being-taught-talk-occupy-wallstreet-133707949.html?guccounter $=1$

Nastor, J. (n.d.) Business Hacks: 21 Simple Mindset Hacks for Entrepreneurs. p. 1 Retrieved from: https://hacktheentrepreneur.com/mindset-hacks-entrepreneurs/

Naughton, J. (2012) New-tech moguls: the modern robber barons? The Guardian, p 5-6. Retrieved from https://www.theguardian.com/technology/2012/jul/01/new-tech-moguls-robber-barons

New York University. (2020, December 7). Peter $M$ Gollwitzer. https://as.nyu.edu/content/nyuas/as/faculty/peter-m-gollwitzer.html

Pride, W. M., Hughes, R. J. Hughes, Kapoor J. R. Kapoor (2015) Foundations of Business Cengage. Boston, MA

Taylor, F. W. (2014), The Principles of Scientific Management, New York, NY, USA and London, UK: Harper \& Brothers, LCCN 11010339, OCLC 233134. Also available from Project Gutenberg

The Free Dictionary (n.d.) Mindset. Retrieved December 17, 2020, from: https: / /www.thefreedictionary.com/mindset\#: :text=mind\%C2\%B7set\&text=1.,2.

Sorenson, O. and Marx, M (2016). Restricting Employment Restrictions, Yale Insights. Retrieved from: 
https://insights.som.yale.edu/insights/restricting-employment-restrictions

Sources of Insight (n.d.) Mindset Defined. Retrieved December 17, 2020, from: https://sourcesofinsight.com/what-is-

mindset/\#: :text=Mindset\%20Defined,\%2C\%20\%E2\%80\%9CWhat\%20is\%20Mindset\%3F\%E2\%80\% 9D\&text=The\%20ideas\%20and\%20attitudes\%20with,(World\%20English\%20Dictionary.)

Wessel, D (2018) Is Lack of Competition Strangling the U.S. Economy? Retrieved from https://hbr.org/2018/03/is-lack-of-competition-strangling-the-u-s-

\title{
ВПЛИВ ДІЛОВОГО МЕНТАЛІТЕТУ НА СПРИЙНЯТТЯ СТУДЕНТАМИ УГОДИ ПРО НЕКОНКУРЕНЦІЮ
}

Лестер Рімс, Доцент кафедри бізнесу Університет Сент-Мері, Лос-Анджелес, Каліфорнія, США https://orcid.org/0000-0002-6883-7072

e-mail:1ester.reams6@gmail.com

\begin{abstract}
Анотація
Одним з основних завдань курсу господарського права є набуття та правильне застосування юридичних понять студентами, які навчаються бізнесу та державного управляння. У цій статті досліджено суперечливість, виявлену в результаті опитування думок студентів щодо угод про неконкуренцію. Дослідження базуеться на гіпотезі, що діловий менталітет, який домінує в американському суспільстві, впливає на сприйняття студентами цього правового поняття. 3 метою розкриття когнітивних чинників, які впливають на сприйняття студентів, автор простежуе становлення та історичну динаміку концепту ділового менталітету в США та його вплив на масове ставлення до правових понять, в результаті чого сформувалося позитивне сприйняття угод про неконкуренцію. Такому позитивному сприйняттю сприяло створення оманливого міфу, який приховував сувору реальність капіталізму за рахунок евфемізації слів "капіталізм" та "капіталіст". Автор пропонує дії щодо формування правильного сприйняття студентами правових понять з метою приведення їх суб'єктивних поглядів та настанов у відповідність із правовою реальністю та науковим світоглядом.
\end{abstract}

Ключові слова: ділове мислення, масове ставлення, сприйняття, угода про неконкуренцію, господарське право, освіта з державного управляння та бізнесу, евфемізація.

Отримано: 04.11.2020

Ухвалено до друку: 28.12.2020

Опубліковано: 26.02.2021

Рімс Л. (2020). Вплив ділового менталітету на сприйняття студентами угоди про неконкуренцію. Вісник Київського національного університету імені Тараса Шевченка. Державне управління, (13), 61-69. https://doi.org/10.17721/2616-9193.2021/13-6/9 